\begin{tabular}{ll}
\hline 臨 & 床 \\
\hline
\end{tabular}

\title{
下眼瞼向き垂直性眼振のみられた小脳梗塞例
}

\author{
結縁 晃治・中田 道広* \\ 増田游・竹久 亨*
}

\section{Downbeat Nystagmus in a Patient with Cerebellar Infarction}

\author{
Koji Yuen and Yu Masuda \\ (Okayama University) \\ Michihiro Nakata and Toru Takehisa \\ (Tsuyama Central Hospital)
}

A man, suffering from hypertension, was affected by dizziness and nausea. These symptoms disappeared in a week under medical treatment.

Six or seven years later, the patient again had severe vertigo, nausea and vomiting again. After this attack, he complained of continuous dizziness. Infarction of the inferior left cerebellar hemisphere was detected by MRI, but no abnormal image was found in the medial part of the cerebellum.

We recognized no neurological signs caused by dysfunction in the cerebellar hemisphere, intension tremor, dyssynergy, etc., but severe disequilibrium was confirmed by Romberg's test, Mann's test and in the squatting position.

In the sitting position, the patient did not exhibit gaze nystagmus, but through Frenzel's glasses we recognized downbeat nystagmus in the right and left eye position. In the supine position with his head hanging down, the patient showed spontaneous downbeat nystagmus. This nystagmus increased with gazing, decreased without gazing and included high frequency pendular-saccadic movements. Caloric nystagmus was well developed in both ears, and visual suppression was also good. A horizontal eye tracking test (ETT) showed smooth eye movements and optokinetic nystagmus (OKN) was well developed.

These otoneurologic findings indicated that 1) there was no difference between right and left eye vestibular functions, 2) his brain stem function was not damaged, 3) neurological lesions were present in the medial part of the cerebellum, flocculus, nodules and vermis. These findings disagreed with those of MRI imaging, suggesting that the medical imaging has its limitations in demonstrating lesions of the central nervous system.

This case showed us that diagnosis of disequilibrium should be based not only on results of medical imaging, but also on otoneurological findings.

Key words: cerebellar infarction, downbeat nystagmus, limitations of medical imaging 


\section{はじめに}

最近の画像診断の進歩, 特に MRI の普及に より，めまい・平衡障害を訴える症例で中枢神 経系，とくに後頭蓋窩の障害も発見されること が多くなってきた。しかしながら神経耳科学的 な検査結果より想定される障害部位と画像上診 断される病巣が必ずしも一致しないことも少な くないように思われる。

今回われわれは，画像上では左小脳半球下部 に梗塞と思われる所見を認めたが，神経耳科学 的検查所見からはむしろ小脳正中部の障害が強 く疑われた症例を経験したので，文献的な考察 を加光て報告する。

\section{症例}

症例：44歳, 男性. 右利き.

主訴：持続する動摇性眩暈.

現病歴：6，7 年前に仕事(郵便配達)中，急 に悪心を伴う動摇感を自覚, 近医を受診したと ころ血圧の上昇 $(180 / 100)$ を指摘され投薬を受 け約 1 週間で軽快した。その後もまれに体動時 に一瞬動摇感を自覚することはあった。

1991年11月某日夕方残業(配達)中気分が悪く なり, バイクに乗っていてバランスがうまくと れないことに気づく．急いで帰宅した後，後頭 部痛・悪心・嘔吐を伴う一過性の自発性回転性 眩暈とそれにひき続いて激しい動摇感を自覚し た. 以来動摇感は持続している.この後津山中 央病院耳鼻咽喉科に扮いて, CT 検査によって 小脳梗塞症の診断を受け投薬を受けた. そして, 1992年 4 月頃までは軽快傾向にあったが，その 後動摇感の再増悪をきたしたため, 岡山大学耳 鼻咽喉科に紹介となった。

既往歴 : 約 10 年前腰椎ヘルニアで 40 日間入院. めまいの初発発作以来，不定期に降圧剂を服用 している．職場の健診でコレステロール高値を 指摘されたことが何度かある．頭部外傷の既往 はない。

職業歴：約 30 年郵便配達に従事. 騒音環境下 での労働経験はなし。

家族歷 : 母親が高血圧・糖尿病.
初診時所見：両側鼓膜は正常，鼻腔・咽頭・ 喉頭に形態・運動とも異常を認めなかった。

検查所見 :

血液検査：当科初診時は正常範囲内.

総コレステロール $150 \mathrm{mg} / \mathrm{dl}$ ，トリグリセライ ド $148 \mathrm{mg} / \mathrm{dl}$.

心電図：洞性頻脈を認めるが，心エコーでは異 常なし。

純音聴力検査 : 左右ともに正常範囲内.

神経学的検査 : 右上腕二頭筋の腱反射六進を認 める. 四肢の異常反射なし. 指鼻試験 - 共同運 動などの小脳機能検査でも異常なし.

平衡機能検査 : Romberg, Mann 検査では閉 眼時に動摇増加，開眼でもそんきょ（しゃがん だ姿勢）をとることができない。裸眼で注視方 向性眼振は認めなかった。フレンツェル眼鏡下 では，座位では眼球を左右側方に偏位させるこ とにより下眼瞼向き垂直性自発眼振を認めた。 また懸垂頭位では眼球が正中位でも下眼瞼向き 垂直性自発眼振を認め, 頭位変換により増強し た.この眼振は裸眼で注視させることにより増 強し，暗所開眼(赤外線フレンツェル眼鏡によ る観察)ではむしろ抑制された(図 $1 ， 2$ ).

カロリックテストでは, 反応良好で左右差な く visual suppression も良好であった. 水平 ETT では平滑な眼球運動を示し(図 3 ), 水平 OKP でも急速相の解発・緩徐相の順応ともに
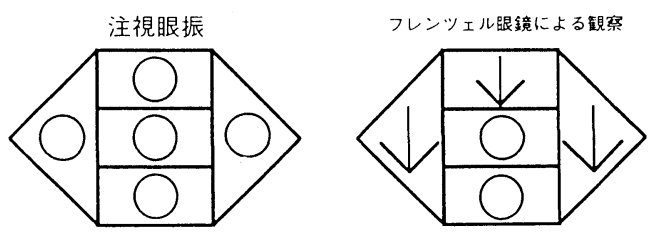

頭位眼振

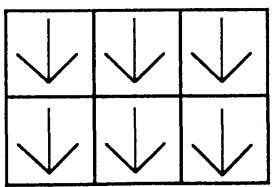

頭位変換眼振

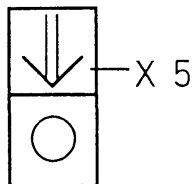

図 1 入院時眼振所見 
良好であった(図 4).

耳単純 X-P : 内耳道拡大・左右差なし. 両側と 多乳突蜂巣発育良好.
頭部 MRI : 左小脳後下部に $\mathrm{T} 1$ 強調画像で低 信号, T2 強調画像で高信号を示す陳旧性小脳 梗塞像を認める(図 6 )。な楞管造影は施行し

$10^{\circ} \mathrm{CAL}$

H

$20 \% \mathrm{sec}^{2}$

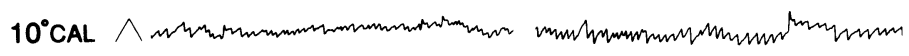

V

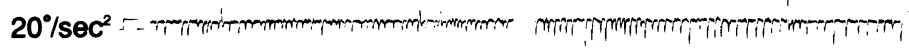

図 2 ENG (仰臥位・懸垂頭位で認めた下眼瞼向き垂直性自発眼振)

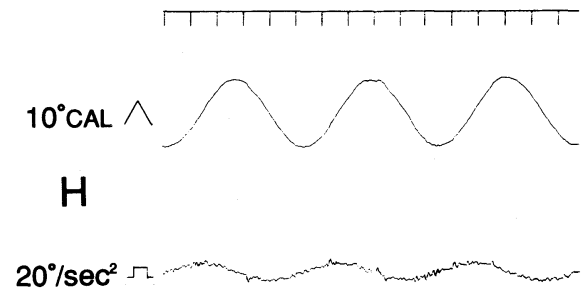

図 3 水平方向 ETT

$10^{\circ} \mathrm{CAL}$
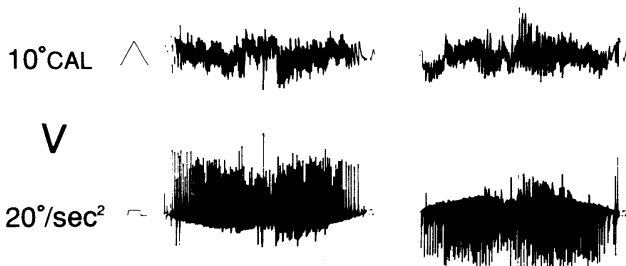

$20 \% \mathrm{sec}^{2}$
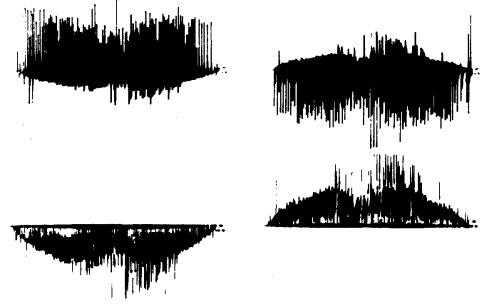

図 4 水平方向 $\mathrm{OKP}$

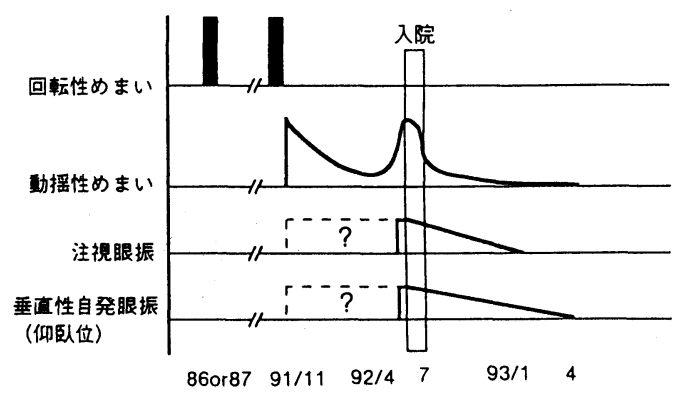

図 5 症状・眼振の経過 
なかった。

入院後経過：小脳の循環不全を改善するため, ヒドロキシェチルデンプン(ヘスパンダー®) 括 よび ATPなどの循環改善剂の点滴静注を扢こ なった。 また少量のアスピリン $(80 \mathrm{mg} / \mathrm{day})$ と イブジラスト (ケタス () 内服併用による抗凝固 療法を抏こなった。その結果自覚的な動摇感は 減弱乙，他覚的にも眼振は減弱し，受診日によ っては全く眼振が観察されないこともある。現
在も外来でひき続き循環改善剤を投与中である. 考察

以前はめまいの原因になるよらな小脳障害で は, 企図振戦や共同運動障害, 四肢の失調, ジ スメトリーなどの内科診断学に記載されている いわゆる「小脳症状」の随伴は必発であると考 学わていた。

しかしメニエール病と小脳血管障害はその初 発症状がきわめて類似していると1969年すでに

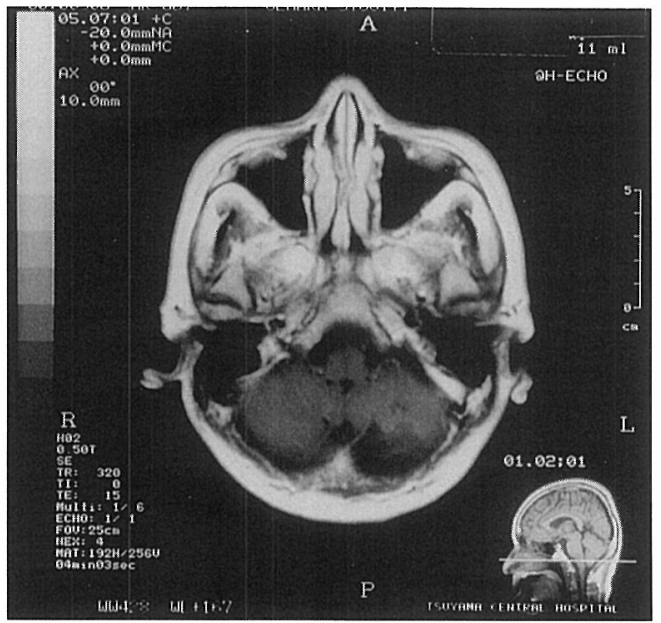

（水平断 $\mathrm{T} 1$ 強調画像）

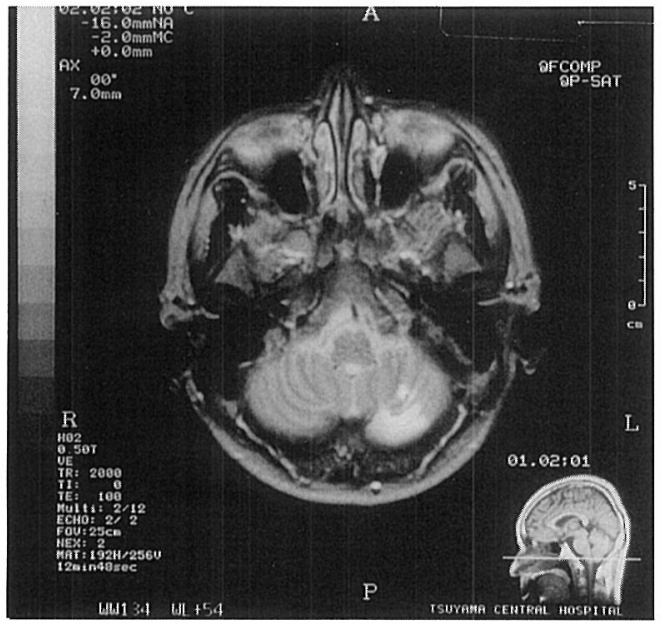

（水平断 $\mathrm{T} 2$ 強調画像）

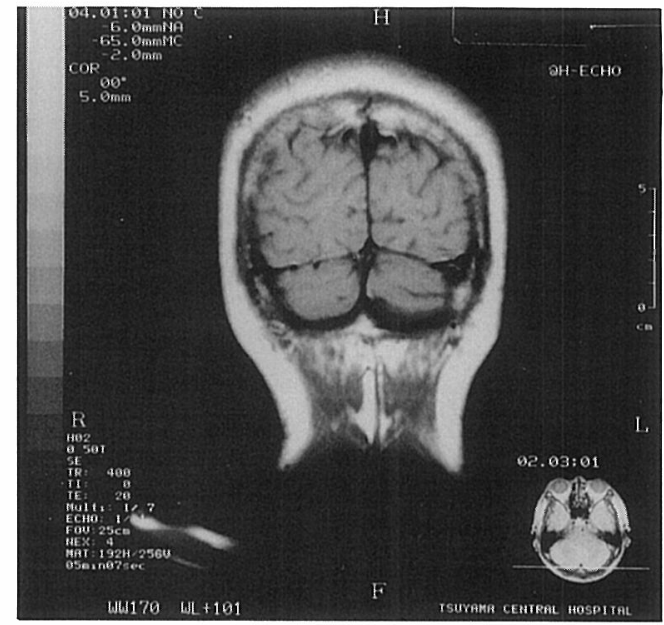

（前頭断 T1 強調画像）

図 6 MRI 所見 
坂田らは指摘している1) が, 同論文中に述べら れているように当科は画像診断的にそれを証明 することには困難が伴なっていた．

ところがX線 CT の性能向上・普及により脳 幹への障害が少ない軽一中等度の小脳病変では, 中枢障害を示す症状が軽微で一過性であり, 内 耳病変類似の症状を示す2) 5) という報告も散見 されるよらになった。

さらに後頭蓋窩病変は, 周囲が骨に囲まれた 解剖学的な特徵から従来のX線 CTによる検索 ではアーチファクトが多く解明には限界がある とされてきたが, MRIの出現によりこの部位 の明瞭な画像が得られるよらになってくる6) と, 今度は神経耳科学的検査から想定される病变部 位と画像上から診断された病変部位が一致しな いことも少なからず認められるようになってき た.

この症例では, 閉眼時左右方向の躯幹動摇も みられるが一定方向性ではなく，むしろそれに 比して前後方向の動摇が大であり，カロリック テストに拉ける眼振の解発も左右差に乏しく, 下眼瞼向き垂直性眼振が認められるなど, 平衡 機能のバランスの左右差があまりみられなかっ た。言い換えれば中心性ないし左右対称性障害 の特徵が認められた. しかしながら一方 ETT やOKP の障害は汪とんどみられず，カロリッ クテストに拈ける visual suppression も障害さ れていないなど, 脳幹の機能低下を示唆する神 経耳科学的所見には乏しいように思われた。 た Wallenberg 症候群でめまい以外にみられる, 患側の Horner 症候群, 顔面の解離性感覚麻痺, 咽喉頭の運動障害, 健側の頸部以下の解離性感 覚麻痺などの延髄背外側部障害をおもわせる神 経症状はみられなかった. そして画像上左小脳 下部に広範な梗塞像が認められるにもかかわら ず，当科受診時には小脳半球の障害に起因する と考えられる神経症状はみられなかった。

後下小脳動脈 $(\mathrm{PICA})$ は前庭小脳 (片葉・小 節)の栄養血管であるので, この血管の梗塞で はめまいは必発の症状である2)とされており,
この症例で MRI 上認められた梗塞もその位置 から PICA 支配領域にあると考えられるので, 本症例のめまいも梗塞のある左側のいわゆる 「前庭小脳」の PICA の循環障害によるものと まず考えられる. しかし左側のみの障害にして は,さき汪ど述べたように平衡機能の左右差が 乏しいように思えるが，前庭小脳を含む小脳の 正中部には画像上は梗塞をおもわせる異常像が みられない。

実験的にはサルの小節を破壊すると下眼瞼向 き垂直性眼振を含む多彩な眼振がみられるとい ら報告7)があり，下眼瞼向き垂直性眼振の責任 病巣については脳幹から小脳虫部とする報 告8) 12) が多い. そして坂田は, 自発性の下眼 瞼向き垂直性眼振を脳幹性と小脳性に分類して いる ${ }^{13)}$ が，本症例では第一眼位での自発眼振 はみられないが, 眼振の性状が高頻度かつ振子 衝動性であること, 側方偏位といら眼球運動を 負荷することにより出現すること，仰臥位で認 められた下眼瞼向き垂直性眼振は注視させると 増強し暗所開眼下ではむしろ抑制されしかも䯚 垂頭位や頭位変換によって増強すること, 水平 OKNが汪とんど障害されていないことなどか ら考皇ると小脳性の要素が強いと考えられる.

また小脳の血管はバリェーションも多く14), PICA は対側のものや, 小脳の他の部分を支配 している血管と豊富な吻合を形成しており，片 葉は前下小脳動脈 (AICA) の支配を受けてい る15) としているものもある. したがって本症 例の初発時の回転性眩量発作は片側の小脳血管 障害に原因をもとめることもできよらが，むし ろ現在の病態は, 片側障害というょりもやはり PICAの血流支配を受けている虫部を含めた小 脳の正中に近い部位全体が循環不全により機能 不全を起こしているものと考えた.

過去には検査上平衡機能の左右差に乏しく明 らかな中枢神経症状を欠くめまい症例に対して は両側内耳障害といら診断が多くなされてきた ように思える. 事実この症例も他医にて両側入 ニェール病といら診断を受けていた。、ストレプ 
トマイシンなどの耳毒性をもつ薬物の全身投与 による障害や頭蓋底骨折など両側の内耳が同程 度に障害されることはあるが，何らかの誘因も なく，乙か子急激に両側の内耳機能低下が括き ることは非常にまれである。

したがって，このような平衡機能の左右差に そしく，中心性ないしは左右対称性の障害を示 す症例で，とくに少しでも中枢障害を思わせる 症状あるいは既往歴のあるものに対しては，積 極的に CT や MRI などの画像診断を拈こなう べきであると考える．しかしながら本症例で示 したように現在の画像診断でも中枢の機能的な 病変を完全に描出し得るものではないので, 精 細な神経耳科学的検查も同時におこない, 両方 の結果から総合して病巣診断を怙こならことが 必要であると思えた。

\section{まとめ}

1 ）画像上では左小脳下部の後下小脳動脈領 域に梗塞像が認められたが，神経耳科学的検査 上では小脳正中部の障害に起因すると考えられ た下眼瞼向き垂直性眼振のみられた症例を報告 した.

2 ）検査上左右の平衡機能の差に乏しく，し かも中心性・左右対称性障害を示唆するめまい 症例では, 中枢障害を疑い積極的に画像診断を おこなら必要があると考えられる。

3 ) 現在の画像診断でも中权病変部位の描出 には限界があり，必ず神経耳科学的検査を併用 して機能的な評価を扣こない，総合的に病巣診 断をする必要があると思われる。

本論文の要旨は, 日本耳鼻咽喉科学会第18回中国 四国連合地方会(平成 4 年10月，広島)にて発表した。

\section{文献}

1）坂田英治, 長島親男, 岩間和生, 他 : 前下小脳 動脈障害の診断 一メニエールとその周辺 第 3 報一。耳鼻臨床 $62: 385 \sim 393,1969$.

2）久保 武, 酒井俊一, 肥塚 泉: 小脳梗塞 5 症 例の経過観察. Equilibrium Res $46: 372 \sim 377$, 1987.
3）久保 武：脳循環不全によるめまい, Equilibrium Res 50 : 339 345, 1991.

4) Duncan GW, Parker SW and Fisher CM : Acute cerebellar infarction in the PICA territory. Arch Neurol $32:$ 364 368, 1975.

5) Guiang jr RL and Ellington OB : Acute pure vertiginous Dysequilibrium in cerebellar infarction. Eur Neurol $16: 11 \sim 15,1977$.

6) Longridge $\mathrm{N}$ and Mallinson A : Arnold-Chiari malformation and the otolaryngologist; place of magnetic resonance imaging and electronystagmograohy. Laryngoscope $95: 335 \sim$ 339, 1985.

7) Fernandez $\mathrm{C}$ and Fredrickson JM : Experimental cerebellar lesions and their effect on vestibular function. Acta Otolaryngol Suppl (Stockh) $192: 52 \sim 62,1964$.

8) Cogan DG : Down-beat nystagmus. Arch Opthalmol $80: 757 \sim 768,1968$.

9）坂田英治, 梅田悦生, 高橋邦丕, 他 : 自発性下 眼瞼向き垂直性眼振の病態生理に関する考察. Equilibrium Res 35 : 85 86, 1964.

10）小松崎篤：自発性下眼瞼向き垂直性眼振の臨床 的考察. 神経内科 $10: 125 \sim 136,1979$.

11）坂田英治 : 検査と診断. 臨床神経耳科学入門. 26 87頁, 医薬歯出版, 東京, 1980 .

12）馬場完仁, 坂田英治, 中沢 宏, 他 : Primary position に扰ける Spontaneous vertical nystagmus の文献的考察と病態生理.耳鼻臨床 79 ： 193 212, 1986.

13）坂田英治：自発性下眼瞼向き垂直性眼振の病態 生理に関する考察. 臨床神経 $16: 958,1976$.

14）亀山正邦：脳底部動脈 Variation の臨床病理学 的意義. 神経進歩 $5: 758 \sim 767,1961$.

15) Duus P : Neurologisch-topische Diagnostik (5. Auflage). pp 231 235, Thieme, Stuttgart, 1990. (日本語訳) 半田肇監訳, 花北順哉訳 : 神経局在 診断 一その解剖, 生理, 臨床一(第 3 版)， 209 ～213頁, 文光堂, 東京, 1988.

原稿受付: 平成 5 年 3 月 18 日 原稿採択: 平成 5 年 7 月 26 日 別刷請求先 : 結縁晃治 干700 岡山市鹿田町2-5-1

岡山大学医学部耳鼻咽喉科学教室 